OPEN ACCESS

Citation: Deborah Moradeke Chukwuma,Abiodun EmmanuelAyodele (2021) Wood micro-morphological characteristics of the Tribe Dalbergieae in Nigeria. Webbia. Journal of Plant Taxonomy and Geography 76(2): 295-306. doi: 10.36253/jopt-11407

Received: June 28, 2021

Accepted: July 11, 2021

Published: September 7, 2021

Copyright: (c) 2021 Deborah Moradeke Chukwuma, Abiodun Emmanuel Ayodele. This is an open access, peerreviewed article published by Firenze University Press (http://www.fupress. com/webbia) and distributed under the terms of the Creative Commons Attribution License, which permits unrestricted use, distribution, and reproduction in any medium, provided the original author and source are credited.

Data Availability Statement: All relevant data are within the paper and its Supporting Information files.

Competing Interests: The Author(s) declare(s) no conflict of interest.

Editor: Alessio Papini

ORCID

DMC: https://orcid.org/0000-00018313-7894

AEA: https://orcid.org/0000-0001-66731197

\section{Wood micro-morphological characteristics of the Tribe Dalbergieae in Nigeria}

\author{
Deborah Moradeke Chukwuma ${ }^{1,2, *}$, Abiodun Emmanuel Ayodele ${ }^{2}$ \\ ${ }^{1}$ Department of Plant Science and Biotechnology, Federal University Oye-Ekiti, Oye-Ekiti, \\ Nigeria \\ ${ }^{2}$ Department of Botany, University of Ibadan, Ibadan, Oyo State, Nigeria \\ ${ }^{\star}$ Corresponding author. E-mail: deborah.chukwuma@fuoye.edu.ng
}

\begin{abstract}
The present study examined the wood micro-characters of 18 species of the tribe Dalbergieae across 4 genera in Nigeria, following previously described methods by other authors. The species are distributed across all geo-ecological zones of the country but more abundant in the southern area which is characterized by higher precipitation. Findings clearly showed that members of the tribe Dalbergieae have more generic/tribal characteristics than delimiting characters. The species have certain unifying characters such as diffuse pore porosity, simple perforation plates, oblique to orthogonal vessel transverse wall inclination, prismatic/styloid crystals, and non-

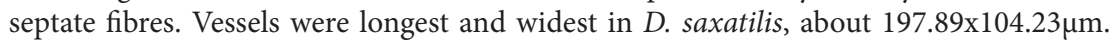
On the contrary, the shortest was observed in D. hostilis - $67.62 \mu \mathrm{m}$ while the narrowest was in $D$. oligophylla $(28.4 \mu \mathrm{m})$. While fibre length was highest in $P$. mildbraedii $(331.22 \mu \mathrm{m} \pm 7.5)$ and smallest in $D$. saxatilis $(0.69 \mu \mathrm{m} \pm 0.0)$, the ray cells were longest in $D$. saxatilis $(185 \mu \mathrm{m})$ and shortest in $P$. santalinoides $(41.82 \mu \mathrm{m})$ respectively. We confirm here that anatomical studies should not be neglected in plant systematics, even though molecular approaches have been the focus in recent times.
\end{abstract}

Keywords: Dalbergieae, ecology, taxonomy, Nigeria, wood anatomy.

\section{INTRODUCTION}

The family Papilionaceae comprises 470 genera and about 14,000 diverse species; and includes small herbs from temperate regions as well as large tropical rainforest trees (Wojciechowski 2003). Together with Caesalpinaceae and Mimosaceae, they form the legume family (Leguminosae), and constitute the third-largest land plant family after Orchidaceae and Asteraceae (Mabberley 1997; Lewis et al. 2005). The Legume Phylogeny Working Group - LPWG (2013) reported some early taxonomists like De Candolle (1825) and Bentham (1865) who had worked on this family as a result of its ecological and economical importance. To date, taxonomists have continued to work on this family and in a more recent work by LPWG (2017), six subfamilies were recognized namely: Caesalpinioideae, Cercidoideae, Detarioideae, Dialioideae, Duparquetioideae, and Papilionoideae (with 503 genera and approxi- 
mately 14,000 species). Evidence from molecular studies confirms the monophyly of legumes and their closeness to the other members of Fabales, which include Polygalaceae, Surianaceae, and Quillajaceae (Lewis et al. 2005).

The tribe Dalbergieae is not a monophyletic clade and comprises 19 tropical woody genera (Polhill 1981; Lavin et al. 2001). It comprises trees, shrubs, and lianas (Gillett et al. 1971). According to Corby (1981) who was the first researcher to consider nodule morphology as a useful character in legume taxonomy, members of Dalbergieae tribe have unique root nodule morphology often referred to as an "Aeschynomenoid" or "Dalbergioid" nodule (Doyle et al. 2000; Kajita et al. 2001; Cardoso et al. 2013).Sprent and James (2007) had ealier noted that approximately $25 \%$ of legume species adapts to crack-entry; a characteristic feature for certain legumes from sub-tropical regions whuch belong to Dalbergioid/ Genistoid clades like species of Aeschynomene, Arachis, and Stylosanthes. As a result of direct access of rhizobia to the cells in the cortex, nodule primordial are developed and repeated cell division of infected cells forms aeschynomenoid nodules. Nevertheless, there are usually no uninfected cells present in the infected zone. Thus, in Aeschynomenoid nodules, the infected regions are always separated from uninfected cells (Fabre et al. 2015; Sharma et al. 2020).

In the work of Lavin et al. (2001), it was reported that within the Dalbergioid clade, there are three wellsupported subclades marked as the Adesmia, Dalbergia, and Pterocarpus clades. Polhill (1981) noted that there appear to be two centres within the Dalbergieae: one around Andira with Hymenolobium, Vatairea, Vataireopsis, Dalbergia, and Machaerium; and another one around Pterocarpus. He highlighted evidence from wood anatomy (Baretta-Kuipers, 1981) which showed that Andira, Hymenolobium, Vatairea, and Vataireopsis have coarser wood structures more typical of members of the Sophoreae than the remaining members of the Dalbergieae. The study of fruit and seedling morphology by Lima (1990) further supported these two centres within the Dalbergieae: one including Andira, Hymenolobium, Vatairea, and Vataireopsis, and the second the remaining genera. Several recent molecular and morphological studies (Lavin et al. 2001; Pennington et al. 2001; Wojciechowski et al. 2004) confirm that these four genera do not belong in the Dalbergioid clade. In Nigeria, the tribe is represented by four genera viz: Andira Lam., Dalbergia L. f, Machaerium Pers. and Pterocarpus Jacq. (Soladoye and Lewis 2003). Generally, all the genera comprise species of great economic importance such as food, oils, fibre, fuel, timber, medicinal uses, amongst others (Wojciechowski 2003).
Herendeen and Miller (2000) had earlier emphasized the importance of wood taxonomy in the identification and classification of flowering plants. LPWG (2013) also reported that morphology can be incorporated into legume phylogeny to address issues in comparative biology and classification. This was reiterated by Maiti et al. (2016) who noted that in phylogenetic studies, the importance of the anatomical features of wood cannot be overemphasized. Given these submissions, only a few documented descriptions are available on the wood anatomical characteristics of African species including those of Leguminosae. Consequently, this study aimed at investigating the wood anatomy of members of the tribe Dalbegieae in Nigeria, in an attempt to identify additional diagnostic characters that could be used for their identification; as well as determining whether the variations in the wood anatomical characters of the members reflect the current circumscription of the tribe. Results obtained may also provide more information on the delimitation of members of this group.

\section{MATERIALS AND METHODS}

\section{Species distribution}

Preliminary species examination was done using previously deposited herbarium specimens at the Forest Herbarium Ibadan (FHI) and University of Ibadan Herbarium (UIH), both listed in Holmgren et al. (1990) from which useful ecological data were obtained and carefully recorded. Additional information was obtained from the Global Biodiversity Information Facility portal (GBIF.org). These were combined, carefully checked for duplicates using the Remove Duplicate tool implemented in Microsoft Excelఠ and thereafter used to generate a generic distributional map of the tribe Dalbergieae in Nigeria (Figure 1) using ArcMap version 10.3.1 (ESRI, Redlands, CA, USA).

\section{Wood microscopic studies}

Fresh wood samples used for this study were collected from the wild. It comprises 18 species as detailed in Table 1. Upon collection, specimens were carefully identified at the Forest Herbarium Ibadan (FHI). Small blocks of about $1 \mathrm{~cm}^{3}$ were obtained from the mature stem of each species; and boiled in water for about two hours to enhance softening of tissues. Three types of sections - transverse section (TS), tangential longitudinal section (TLS), and radial longitudinal section (RLS); 


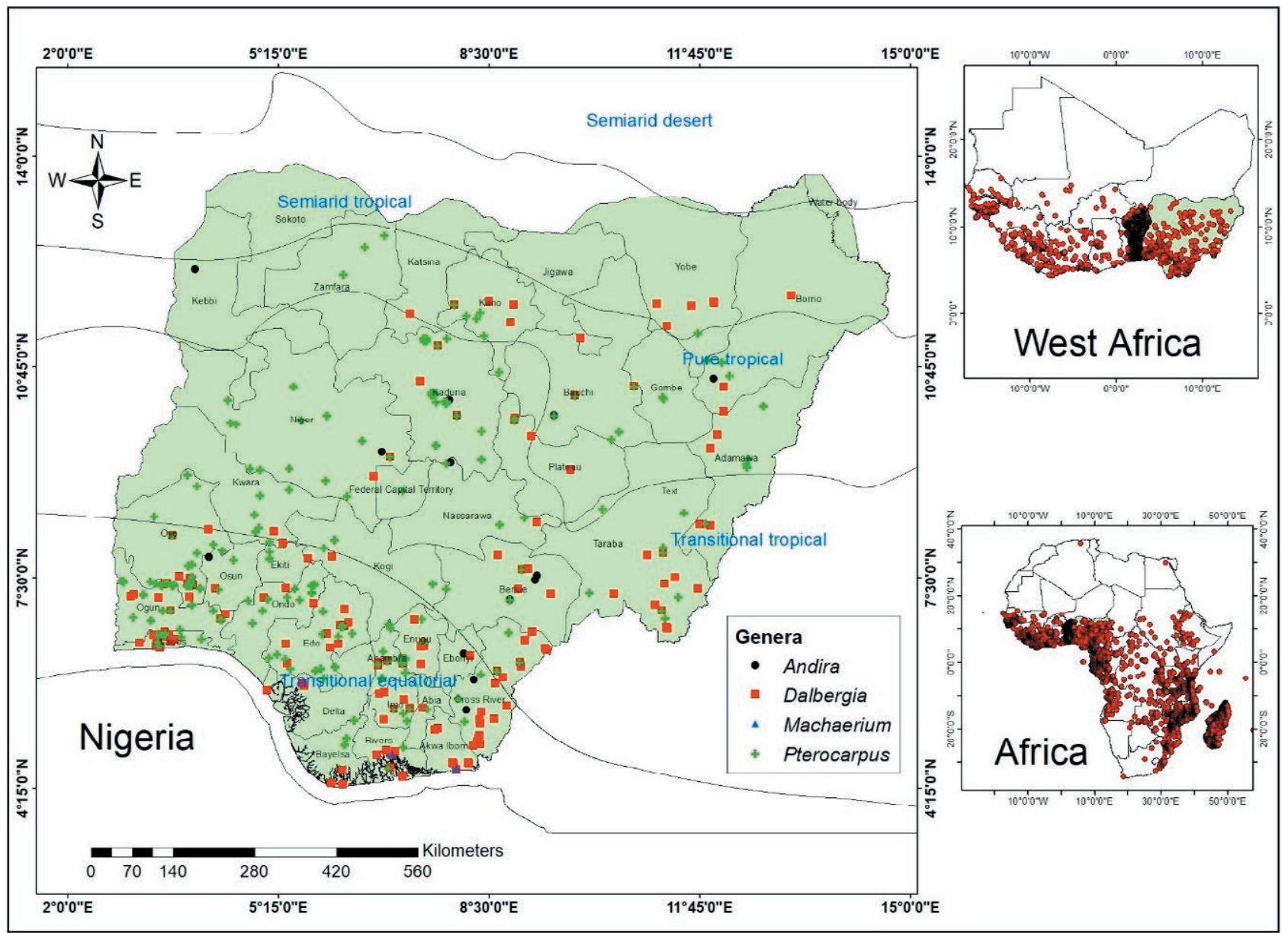

Figure 1. Distribution of Dalbergieae species in Nigeria.

all $10 \mu \mathrm{m}$ thick were obtained with the aid of a sledge microtome, and thereafter preserved in 50\% ethanol. The sections were stained with Safranin O and left for about three minutes, rinsed in clear water and counter-stained with Alcian blue, and also left for about three minutes before they were rinsed again in water. For dehydration and differentiation, the counter-stained sections were treated with series of ethanol - 50\%, 70\%, 80\%, 90\%, and $100 \%$ (absolute ethanol) respectively. For the removal of traces of water and ethanol, the differentiated sections passed through two series of absolute xylene.

For maceration of tissues, slices of each wood sample were put in a beaker containing Schulz's fluid (obtained by mixing equal volume of $10 \%$ chromic acid and $10 \%$ nitric acid as described by Ogbonnaya et al. (1997), Akinloye et al. (2012), and Oladipo and Oyaniran (2013). The macerated specimens were rinsed in water about five times and later preserved in 50\% ethanol. They were then stained first with Safranin O, left for about three minutes; rinsed in water, and then counter-stained with Alcian blue, left for another three minutes, and then rinsed. They were also subjected to series of treatments in ethanol $(50 \%, 70 \%, 80 \%, 90 \%$, and $100 \%)$ for dehydration and differentiation.

All mounted slides were carefully studied under an Olympus $\odot$ light microscope, while quantitative and qualitative data were observed and recorded accordingly. Some of the quantitative data include pore diameter, pore per square, ray height, ray width, fibre length, fibre width, fibre lumen, fibre wall thickness, vessel length, and vessel width. All microscopic measurements were taken with the aid of ocular and stage micrometers. Qualitative data include pore shape, dominant vessel type, inclination, type of axial parenchyma amongst others. Photomicrographs of all slides were also taken using a Sony digital camera mounted on the microscope. All terminologies used for the description of microscopic features follow the International Association of Wood Anatomists' list of microscopic features for hardwood identification (IAWA Committee 1989). 
Table 1. List of Dalbergieae species studied.

\begin{tabular}{llcc}
\hline S/n & Species & Habit & Location \\
\hline 1. & Andira inermis (W.Wright.) Kunth ex DC & Tree & Ago-Are, Oyo State \\
2. & Dalbergia albiflora A. Chev. ex Hutch. \& Dalziel & Shrub & Calabar, Cross River State \\
3. & Dalbergia ecastaphyllum (L.) Taub. & Shrub & Lagoon Front, UNILAG \\
4. & Dalbergia hostilis Benth. & Shrub/small tree & Obudu, Cross River State \\
5. & Dalbergia lactea Vatke & Shrub & New Bussa, Niger State \\
6. & Dalbergia latifolia Roxb. & Tree & Ibadan, Oyo State \\
7. & Dalbergia melanoxylon Guill. \& Perr. & Tree & Bauchi \\
8. & Dalbergia oligophylla Bak. ex Hutch. \& Dalz. & Shrub & Obudu Cattle Ranch, Cross River State \\
9. & Dalbergia rufa G. Don & Shrub/liana & Ibadan \\
10. & Dalbergia saxatilis Benth. & Shrub & Efon-Alaye, Ekiti State \\
11. & Dalbergia sissoo Roxb. ex DC. & Tree & Ibadan, Oyo State \\
12. & Machaerium lunatum (L.f.) Ducke & Shrub/small tree & Okitipupa, Ondo State \\
13. & Pterocarpus erinaceus Poir. & Tree & Olokemeji, Ogun state \\
14. & Pterocarpus lucens Lepr. ex Guill. et Perrott. & Shrub & Mokwa road, Niger State \\
15. & Pterocarpus mildbraedii Harms & Tree & FRIN Premises, Ibadan \\
16. & Pterocarpus osun Craib & Tree & Ibadan, Oyo State \\
17. & Pterocarpus santalinoides L'Hérit. ex DC & Tree & Olokemeji, Ogun state \\
18. & Pterocarpus soyauxii Taub. & Tree & Umuahia, Abia State \\
\hline
\end{tabular}

\section{Data analysis}

All quantitative data were subjected to multivariate analyses using PAlaeontological STatistics version 4.02 (PAST; Hammer et al. 2001).

\section{RESULTS}

The preliminary diversity studies showed that members of the tribe Dalbergieae are distributed across all the geo-ecological zones of Nigeria (Figure 1). Specifically, the transitional equatorial climatic zone of Nigeria appears to be the region of the widest distribution.

Qualitative and quantitative wood characteristics of the studied Dalbargieae species are presented in tables 2 and 3 respectively, while illustrations are presented in figures 2-5. Diffuse porosity, oblique to transverse vessel inclination, and simple perforation plates were observed in all the species, while the vessel pore was generally circular, oval, and short cylindrical in all but $P$. mildbraedii and P. santalinoides. Other variations in vessel pore observed were short rectangular, arc, polygonal and triangular types. The pitting of the vessel was commonly simple in all the species but also alternate in most of the species including $P$. mildbraedii, $P$. santalinoides, $P$. erinaceus, D. albiflora, D. oligophylla, D. sissoo, Dalbergia lactea, D. ecastaphyllum, D. hostilis, D. lunatum, $P$. osun and D. latifolia; and in addition, spiral in D. latifo- lia and A. inermis. Tyloses, which are outgrowths from adjacent ray or axial parenchyma cell through a pit in a vessel wall, were also seen in 13 of the species but absent in $P$. santalinoides, D. melanoxylon, D. rufa, D. latifolia and M. lunatum. Only P. osun had secretory ducts present; while ray type was mainly uniseriate, non-storied and heterogeneous (Table 2; Figures 2-4).

Fibres were generally non-septate and non-storied (Figure 5), with narrow walls about $1.0 \mu \mathrm{m}$ thick except in D. saxatilis $(2.75 \mu \mathrm{m} \pm 0.2)$; and large lumen with no pitting. Fibre length ranged between $0.69 \mu \mathrm{m} \pm 0.0$ (D. saxatilis) and $331.22 \mu \mathrm{m} \pm 7.5$ (P. mildbraedii) while lumen diameter was between $3.69 \mu \mathrm{m} \pm 0.1$ (D. oligophylla) and $6.53 \mu \mathrm{m} \pm 0.1$ (P. soyauxii) as shown in Table 3 .

Pore diameter was generally small in all the species studied ranging from $0.04 \mu \mathrm{m}$ (in $M$. lunatum and $D$. malanoxylon) to $0.09 \mu \mathrm{m}$ (in P. osun and P. souyauxii). Ray cells observed were longer than wide, ray height measurements were between $41.82 \mu \mathrm{m}$ in P. santalinoides and $185 \mu \mathrm{m}$ in Dalbergia saxatilis while ray width measured between $4.33 \mu \mathrm{m}$ in $D$. rufa and $26.93 \mu \mathrm{m}$ in $D$. saxatilis. Vessel length measured after maceration was between $67.2 \mu \mathrm{m}$ in D. hostilis and $197.89 \mu \mathrm{m}$ in Dalbergia saxatilis. However, the widest vessel was observed in D. saxatilis $(104.23 \mu \mathrm{m})$ while the least was seen in D. oligophylla $(28.4 \mu \mathrm{m})$, as noted in Table 3. Correlation coefficients of the examined wood characters are also presented in Table 4.

Further results as revealed through the dendrogram and scatter plot of species showed that there are three (3) 


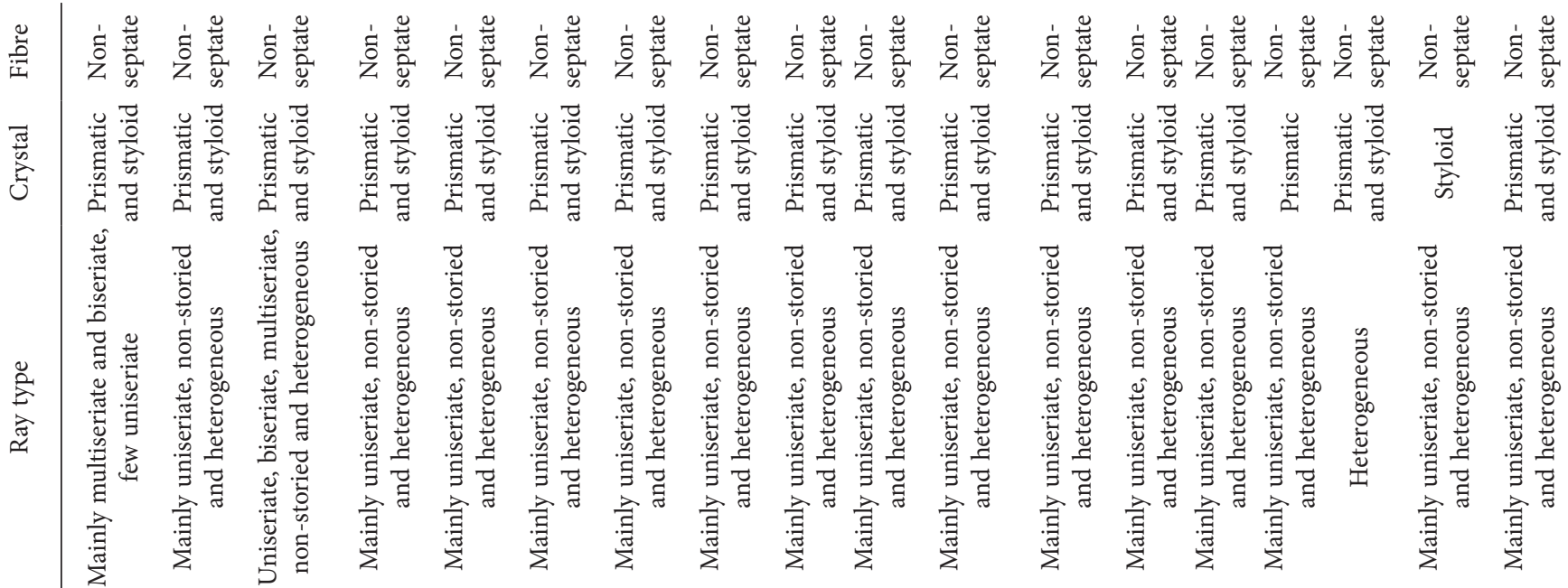

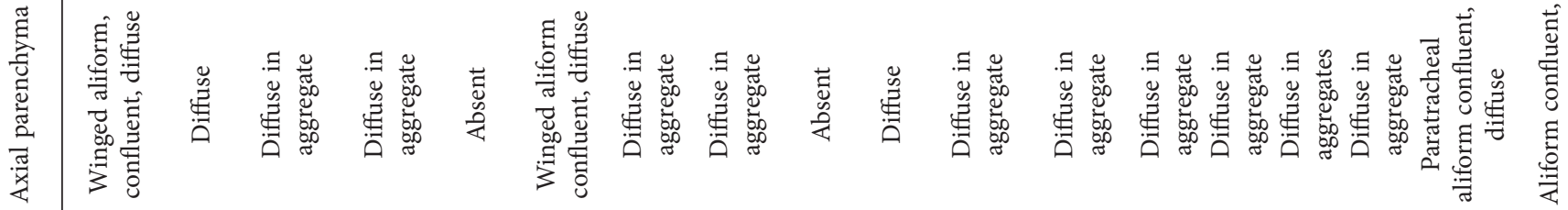

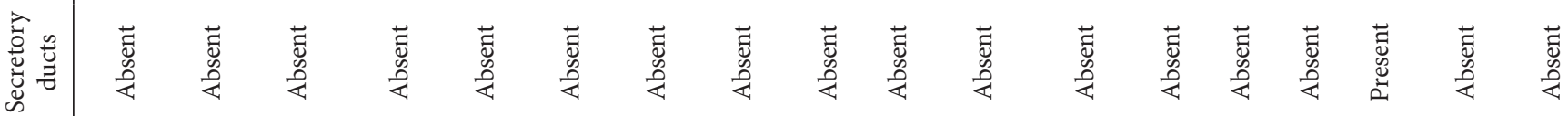

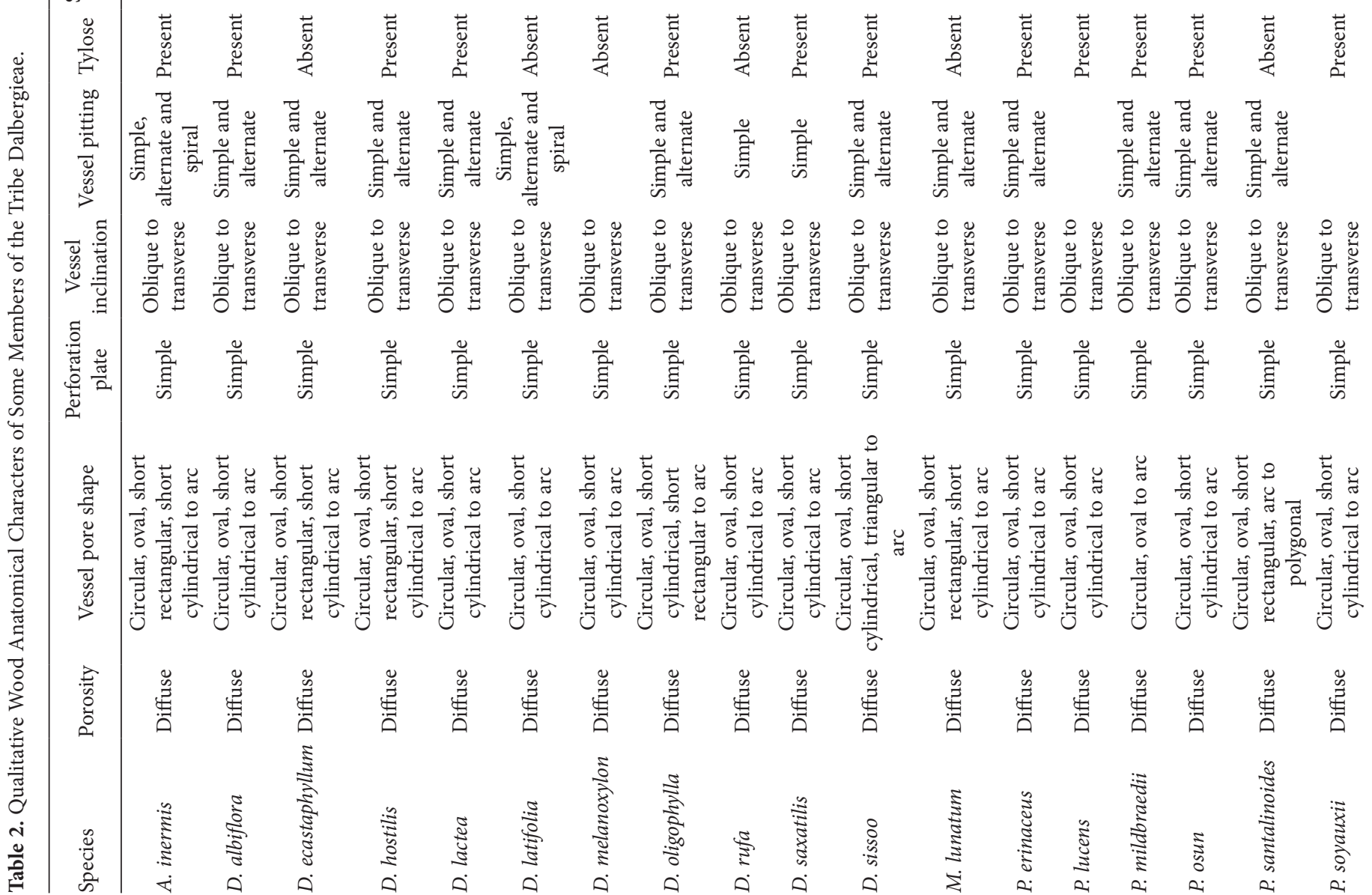


Table 3. Quantitative wood anatomical characters of some members of the tribe Dalbergieae (Mean \pm S.E).

\begin{tabular}{|c|c|c|c|c|c|c|c|c|c|c|}
\hline Species & PD & PPS & RH & RW & FL & FW & FLU & FWT & VL & VW \\
\hline A. inermis & $0.08 \pm 0.8$ & $2.47 \pm 0.1$ & $99.03 \pm 4.8$ & $13.58 \pm 1.2$ & $185.08 \pm 5.4$ & $6.43 \pm 0.2$ & $4.45 \pm 0.2$ & $1 \pm 0$ & $76.23 \pm 2.4$ & $31.14 \pm 0.9$ \\
\hline D. albiflora & $0.06 \pm 0.6$ & $3.57 \pm 0.2$ & $55.75 \pm 2.1$ & $5.47 \pm 0.2$ & $165.8 \pm 3.5$ & $6.33 \pm 0.1$ & $5.07 \pm 0.7$ & $0.99 \pm 0$ & $77.24 \pm 2.7$ & $29.64 \pm 1.0$ \\
\hline D. ecastaphyllum & $0.08 \pm 0.8$ & $2.00 \pm 0.1$ & $61.47 \pm 2.3$ & $7.53 \pm 0.2$ & $206.01 \pm 4.2$ & $7.21 \pm 0.1$ & $5.23 \pm 0.1$ & $1 \pm 0$ & $82.64 \pm 2.4$ & $36.85 \pm 1.1$ \\
\hline D. hostilis & $0.06 \pm 0.6$ & $2.4 \pm 0.1$ & $58.9 \pm 2.3$ & $5.08 \pm 0.1$ & $231.7 \pm 4.5$ & $6.69 \pm 0.1$ & $4.69 \pm 0.1$ & $1 \pm 0$ & $67.62 \pm 1.8$ & $30.67 \pm 0.8$ \\
\hline D. lactea & $0.07 \pm 0.9$ & $1.78 \pm 0.1$ & $67.03 \pm 2.3$ & $5.7 \pm 0.2$ & $199.59 \pm 6.6$ & $7.51 \pm 0.2$ & $5.44 \pm 0.2$ & $1 \pm 0$ & $84.11 \pm 3.1$ & $35.84 \pm 1.2$ \\
\hline D. latifolia & $0.08 \pm 0.7$ & $1.71 \pm 0.1$ & 0 & 0 & $271.79 \pm 7.1$ & $6.57 \pm 0.1$ & $4.6 \pm 0.1$ & $1 \pm 0$ & $78.12 \pm 2.0$ & $47.92 \pm 1.9$ \\
\hline D. melanoxylon & $0.04 \pm 0.4$ & $9.42 \pm 0.5$ & $43.88 \pm 1.8$ & $5.21 \pm 0.2$ & $183.64 \pm 3.7$ & $6.44 \pm 0.1$ & $4.42 \pm 0.1$ & $1 \pm 0$ & $76.17 \pm 2.9$ & $35.32 \pm 1.0$ \\
\hline D. oligophylla & $0.06 \pm 0.6$ & $2.64 \pm 0.1$ & $104.74 \pm 5.3$ & $7.7 \pm 0.3$ & $150.98 \pm 4.1$ & $5.67 \pm 0.1$ & $3.69 \pm 0.1$ & $1 \pm 0$ & $73.53 \pm 2.2$ & $28.4 \pm 0.7$ \\
\hline D. rufa & $0.06 \pm 0.5$ & $3.35 \pm 0.2$ & $49.29 \pm 2.1$ & $4.33 \pm 0.1$ & $166.41 \pm 4.7$ & $6.63 \pm 0.1$ & $4.55 \pm 0.1$ & $1 \pm 0$ & $105.42 \pm 4.8$ & $31.83 \pm 0.9$ \\
\hline D. saxatilis & $0.06 \pm 3.7$ & $3.2 \pm 0.2$ & $185.13 \pm 12.6$ & $26.93 \pm 8.8$ & $0.69 \pm 0.0$ & $10.2 \pm 0.2$ & $4.69 \pm 0.4$ & $2.75 \pm 0.2$ & $197.89 \pm 8.1$ & $104.23 \pm 3.7$ \\
\hline D. sissoo & $0.07 \pm 0.6$ & $3.16 \pm 0.2$ & $56.97 \pm 2.7$ & $6.7 \pm 0.2$ & $220.52 \pm 4.3$ & $6.12 \pm 0.1$ & $4.19 \pm 0.1$ & $1 \pm 0$ & $59.57 \pm 1.3$ & $31.15 \pm 0.8$ \\
\hline M. lunatum & $0.04 \pm 0.3$ & $3.23 \pm 0.1$ & $57.7 \pm 1.9$ & $4.56 \pm 0.1$ & $247.33 \pm 8.6$ & $7.34 \pm 0.2$ & $5.21 \pm 0.2$ & $1 \pm 0$ & $91.65 \pm 3.2$ & $39.15 \pm 1.5$ \\
\hline P. erinaceus & $0.08 \pm 1.2$ & $3.66 \pm 0.2$ & $59.56 \pm 2.7$ & $4.6 \pm 0.1$ & $297.64 \pm 7.1$ & $6.83 \pm 0.1$ & $4.84 \pm 0.1$ & $1 \pm 0$ & $86.2 \pm 1.2$ & $56.74 \pm 1.6$ \\
\hline P. lucens & $0.07 \pm 0.6$ & $5.22 \pm 0.2$ & $46.92 \pm 2.3$ & $5.46 \pm 0.2$ & $213.31 \pm 4.5$ & $7.65 \pm 0.1$ & $5.66 \pm 0.1$ & $1 \pm 0$ & $72.37 \pm 1.9$ & $30.07 \pm 1.0$ \\
\hline P. mildbraedii & $0.07 \pm 0.8$ & $2.22 \pm 0.1$ & $55.86 \pm 3.1$ & $7.33 \pm 0.3$ & $331.22 \pm 7.5$ & $7.05 \pm 0.1$ & $5.06 \pm 0.1$ & $1.01 \pm 0$ & $75.47 \pm 1.8$ & $37.27 \pm 1.5$ \\
\hline P. osun & $0.09 \pm 0.9$ & $2.02 \pm 0.1$ & 0 & 0 & $274.95 \pm 9.5$ & $6.4 \pm 0.1$ & $4.4 \pm 0.1$ & $1 \pm 0$ & $82.84 \pm 2.6$ & $37.95 \pm 1.1$ \\
\hline P. santalinoides & $0.08 \pm 1.1$ & $3.58 \pm 0.2$ & $41.82 \pm 1.6$ & $4.78 \pm 0.1$ & $262.84 \pm 5.5$ & $7.29 \pm 0.1$ & $5.6 \pm 0.1$ & $1 \pm 0$ & $83.04 \pm 1.7$ & $47.29 \pm 1.1$ \\
\hline P. soyauxii & $0.09 \pm 0.9$ & $2.88 \pm 0.1$ & $48.77 \pm 2.3$ & $6.9 \pm 0.2$ & $259.86 \pm 5.3$ & $8.56 \pm 0.1$ & $6.53 \pm 0.1$ & $1 \pm 0$ & $90.76 \pm 2.5$ & $54.15 \pm 2.7$ \\
\hline
\end{tabular}

Key: PD: Pore diameter; PPS - Pore per square; RH - Ray height; RW - Ray width; FL- Fibre length; FW - Fibre width; FLU - Fibre lumen; FWT - Fibre wall thickness; VL- Vessel length; VW - Vessel width. All measurements in $\mu \mathrm{m}$.

Table 4. Pearson's correlation coefficients of the examined wood anatomical characters.

\begin{tabular}{|c|c|c|c|c|c|c|c|c|c|c|}
\hline & $\mathrm{PD}$ & PPS & $\mathrm{RH}$ & RW & FL & FW & FLU & FWT & $\mathrm{VL}$ & VW \\
\hline PD & 1.00 & & & & & & & & & \\
\hline PPS & -0.515 & 1.00 & & & & & & & & \\
\hline $\mathrm{RH}$ & -0.306 & -0.028 & 1.00 & & & & & & & \\
\hline RW & -0.157 & -0.006 & $0.943^{\star}$ & 1.00 & & & & & & \\
\hline FL & 0.461 & -0.171 & -0.779 & -0.756 & 1.00 & & & & & \\
\hline FW & 0.066 & -0.039 & 0.527 & 0.665 & -0.401 & 1.00 & & & & \\
\hline FLU & 0.330 & -0.041 & -0.168 & -0.064 & 0.276 & 0.553 & 1.00 & & & \\
\hline FWT & -0.172 & -0.008 & 0.772 & $0.865^{\star}$ & -0.732 & 0.765 & -0.082 & 1.00 & & \\
\hline VL & -0.162 & -0.034 & 0.694 & 0.778 & -0.687 & $0.805^{\star}$ & 0.038 & $0.940^{*}$ & 1.00 & \\
\hline VW & 0.080 & -0.048 & 0.563 & 0.685 & -0.429 & $0.826^{\star}$ & 0.153 & $0.880^{\star}$ & $0.890^{*}$ & 1.00 \\
\hline
\end{tabular}

Key: PD: Pore diameter; PPS - Pore per square; RH - Ray height; RW - Ray width; FL- Fibre length; FW - Fibre width; FLU - Fibre lumen; FWT - Fibre wall thickness; VL- Vessel length; VW - Vessel width.

main clusters (Figure 6, 7). 7 species formed cluster 1, 10 species formed cluster 2 , while $D$. saxatilis occupied an isolated position, thereby representing an outlier.

Similarity indices (euclidean distance) for the species of the tribe Dalbergiae based on the wood anatomical characters is shown in Table 5. The least coefficient was observed between $D$. lactea \& D. ecastaphyllum (8.88), followed by P. osun \& D. latifolia (11.48), and then $P$. souyauxii \& P. santalinoides (13.09); while the highest was observed between $P$. mildbraedii \& D. saxa- tilis (381.89). This was closely followed by $P$. osun $\& D$. saxatilis (357.59), and D. saxatilis \& D. latifolia (355.01) respectively. Interestingly, the dissimilarity coefficients between $D$. saxatilis and the remaining species were very high compared to other taxa when compared; and this observation is also in support of the illustrations on the dendrogram and scatter-plot of the species where it occupied isolated positions. 

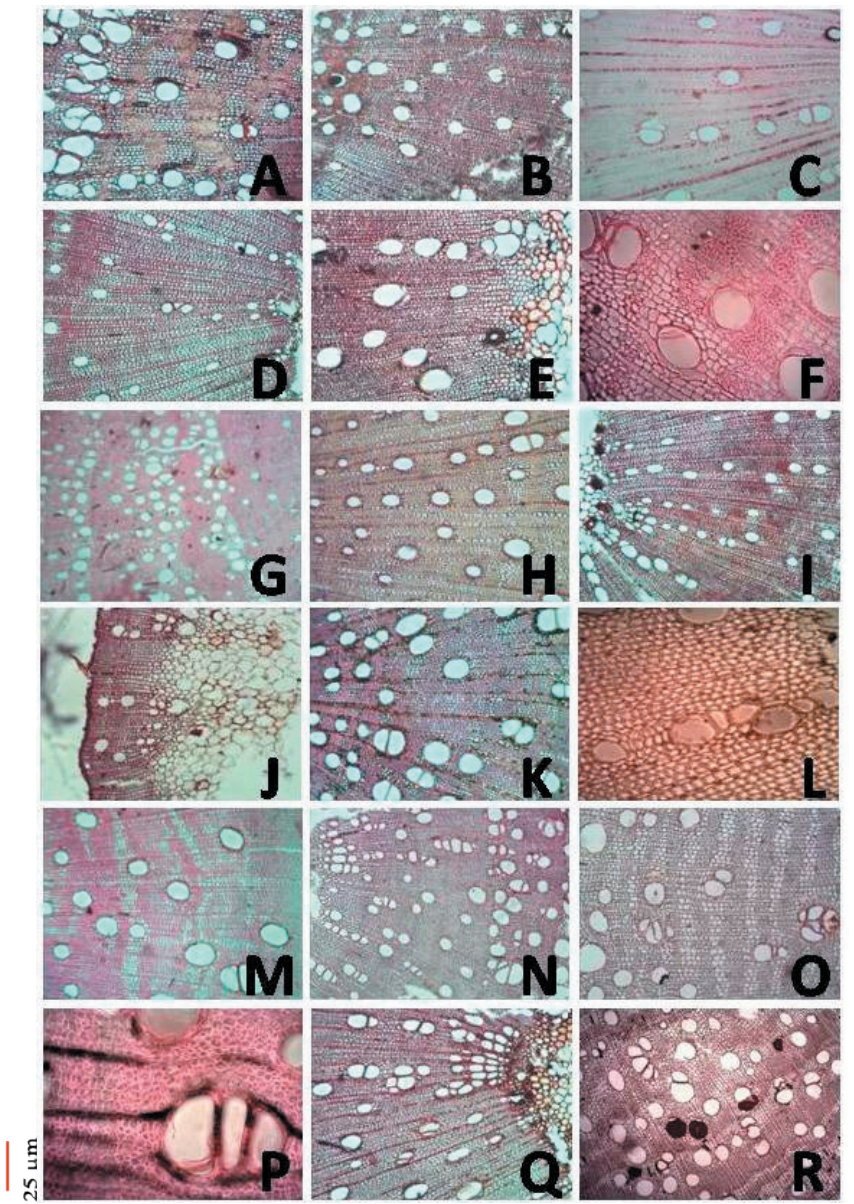

Figure 2. Transverse Sections (TS) of Dalbergieae species in Nigeria. Mg.x400. A- Andira inermis; B-Dalbergia albiflora; C- Dalbergia ecastaphyllum; D- Dalbergia hostilis; E-Dalbergia lactea; F-Dalbergia latifolia; G-Dalbergia melanoxylon; H-Dalbergia oligophylla; I-Dalbergia rufa; J-Dalbergia saxatilis; K-Dalbergia sissoo; L-Machaerium lunatum; M-Pterocarpus erinaceus; N-Pterocarpus lucens; O-Pterocarpus mildbraedii; P-Pterocarpus osun; Q-Pterocarpus santalinoides; R-Pterocarpus soyauxii

\section{DISCUSSION}

Shreds of evidence from anatomical studies have been used for the delimitation of taxa as reported by Metcalfe and Chalk (1979); Aguoru and Okoli (2008), Arogundade and Adedeji (2019). Carlquist in 1961 had earlier submitted that wood anatomical characters are of taxonomic and phylogenetic importance, while more recently, Liu et al. (2020) noted that anatomical properties of wood relate closely to several factors amongst which is their genetic origin. In the current study, the wood anatomy of the 18 species of the tribe Dalbergieae studied provided more information on their taxonomic placement rather than characters that can be used for their delimitation. Gen-

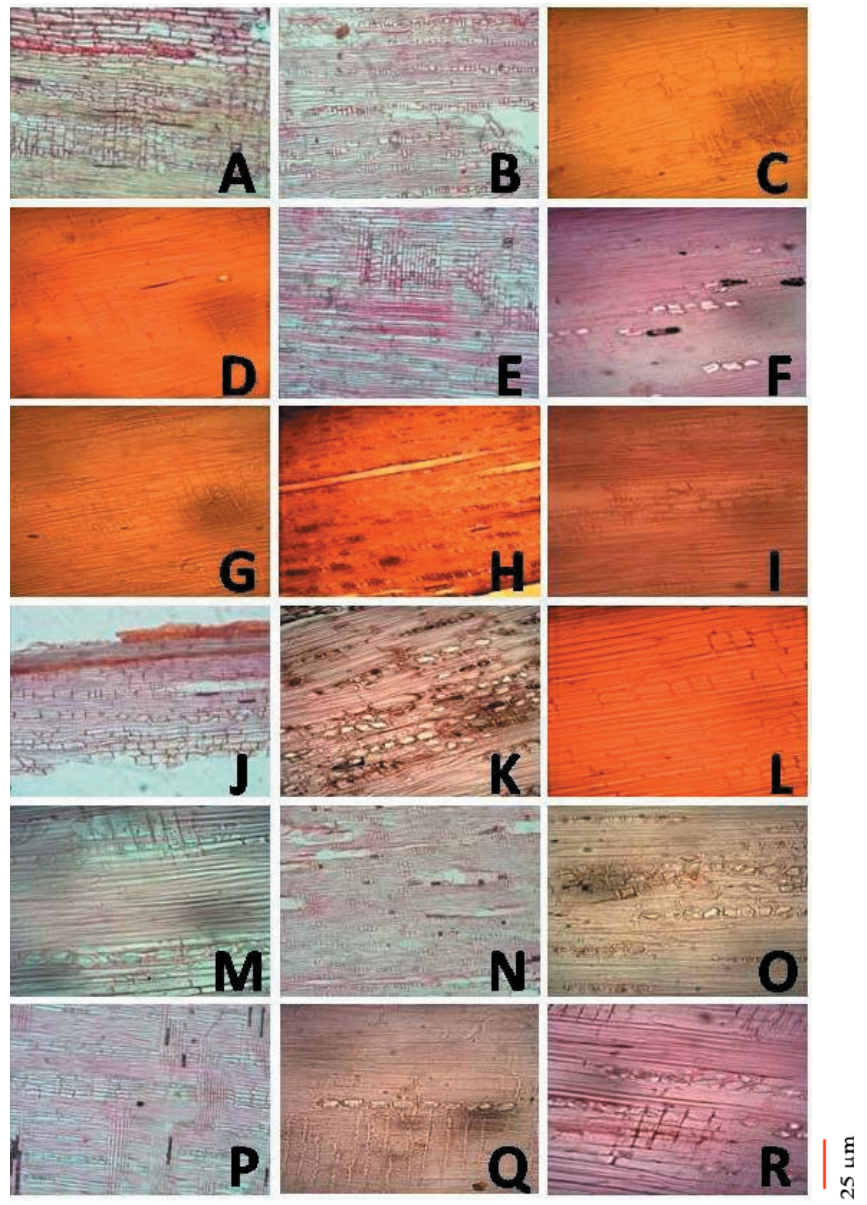

Figure 3. Radial Longitudinal Sections (RLS) of Dalbergieae species in Nigeria. Mg.x400. A- Andira inermis; B- Dalbergia albiflora; C- Dalbergia ecastaphyllum; D- Dalbergia hostilis; E-Dalbergia lactea; F-Dalbergia latifolia; G-Dalbergia melanoxylon; H-Dalbergia oligophylla; I-Dalbergia rufa; J-Dalbergia saxatilis; K-Dalbergia sissoo; $\mathbf{L}$-Machaerium lunatum; M-Pterocarpus erinaceus; N-Pterocarpus lucens; O-Pterocarpus mildbraedii; P-Pterocarpus osun; Q-Pterocarpus santalinoides; R-Pterocarpus soyauxii

erally, porosity is diffuse; perforation plate simple; tyloses present in all except $P$. santalinoides, D. melanoxylon, D. rufa, D. ecastaphyllum, M. lunatum, and D. latifolia; secretory ducts absent in all except $P$. osun, while fibre is non-septate in all the examined species. In furtherance, crystal is prismatic in P. mildbraedii, styloid in P. santalinoides, but a combination of both in the remaining 16 species studied. Vessel inclination is oblique to transverse while pitting is simple and alternately positioned. The presence of solitary vessels as also observed in this work is an indication of species primitiveness earlier reported by Oladipo and Oyaniran (2013).

Certain wood characters have more importance than others in the taxonomic understanding of the taxa stud- 

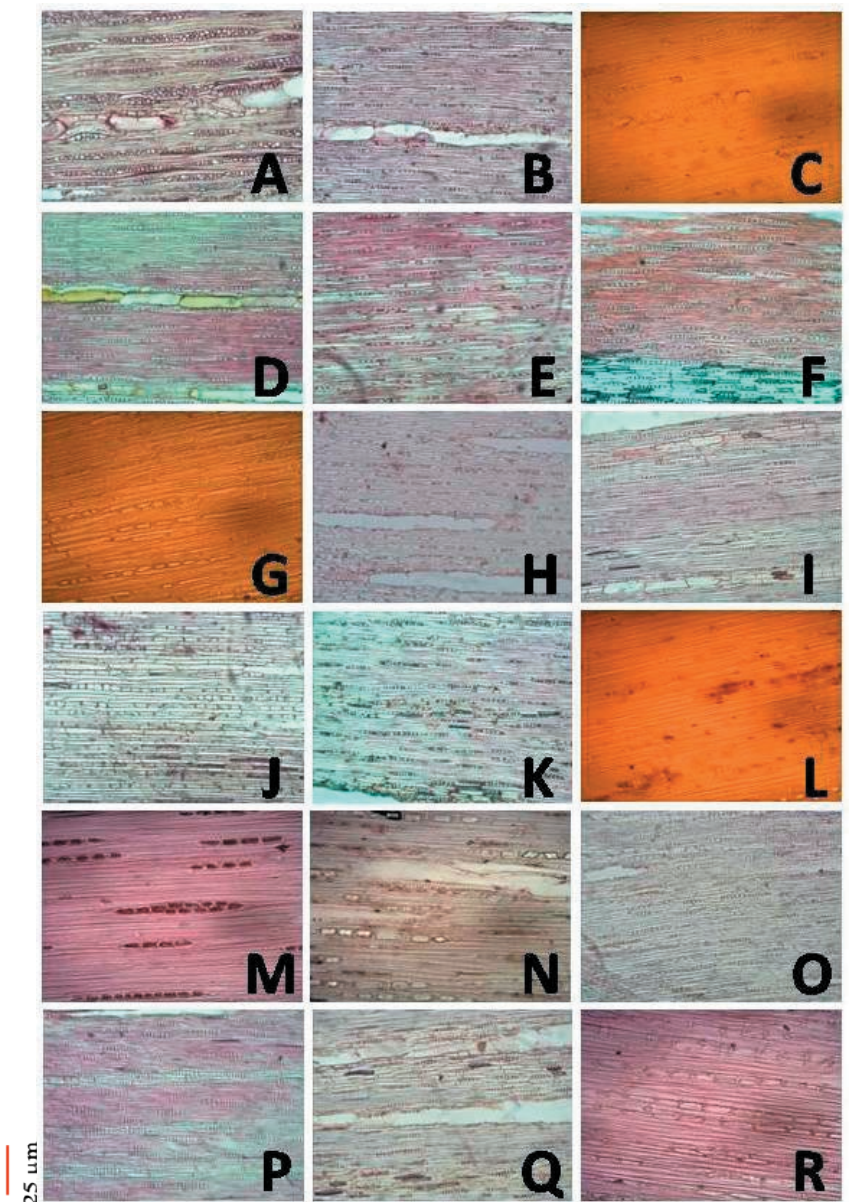

Figure 4. Tangential Longitudinal Sections (TLS) of Dalbergieae species in Nigeria. Mg.x400. A- Andira inermis; B- Dalbergia albiflora; C- Dalbergia ecastaphyllum; D- Dalbergia hostilis; E-Dalbergia lactea; F-Dalbergia latifolia; G-Dalbergia melanoxylon; H-Dalbergia oligophylla; I-Dalbergia rufa; J-Dalbergia saxatilis; K-Dalbergia sissoo; L-Machaerium lunatum; M-Pterocarpus erinaceus; N-Pterocarpus lucens; O-Pterocarpus mildbraedii; P-Pterocarpus osun; Q-Pterocarpus santalinoides; R-Pterocarpus soyauxii.

ied. Pearson's correlation of the wood characters in Dalbergieae showed that ray height is highly correlated with ray width, ray width is highly correlated with fibre wall thickness, fibre width is highly correlated with vessel length and vessel width. Further, fibre wall thickness is very highly correlated with vessel length and vessel width, while vessel length and vessel width are also highly correlated. These combinations could be used to distinguish the taxa. It was also observed that all species studied have similar vessel shapes at a transverse plane, from circular, oval, short cylindrical, short rectangular, arc to polygonal. Kribs (1937) in Metcalf and Chalk (1989) considered the lack of axial parenchyma in the wood of plants as a primitive character, on the contrary, the species studied
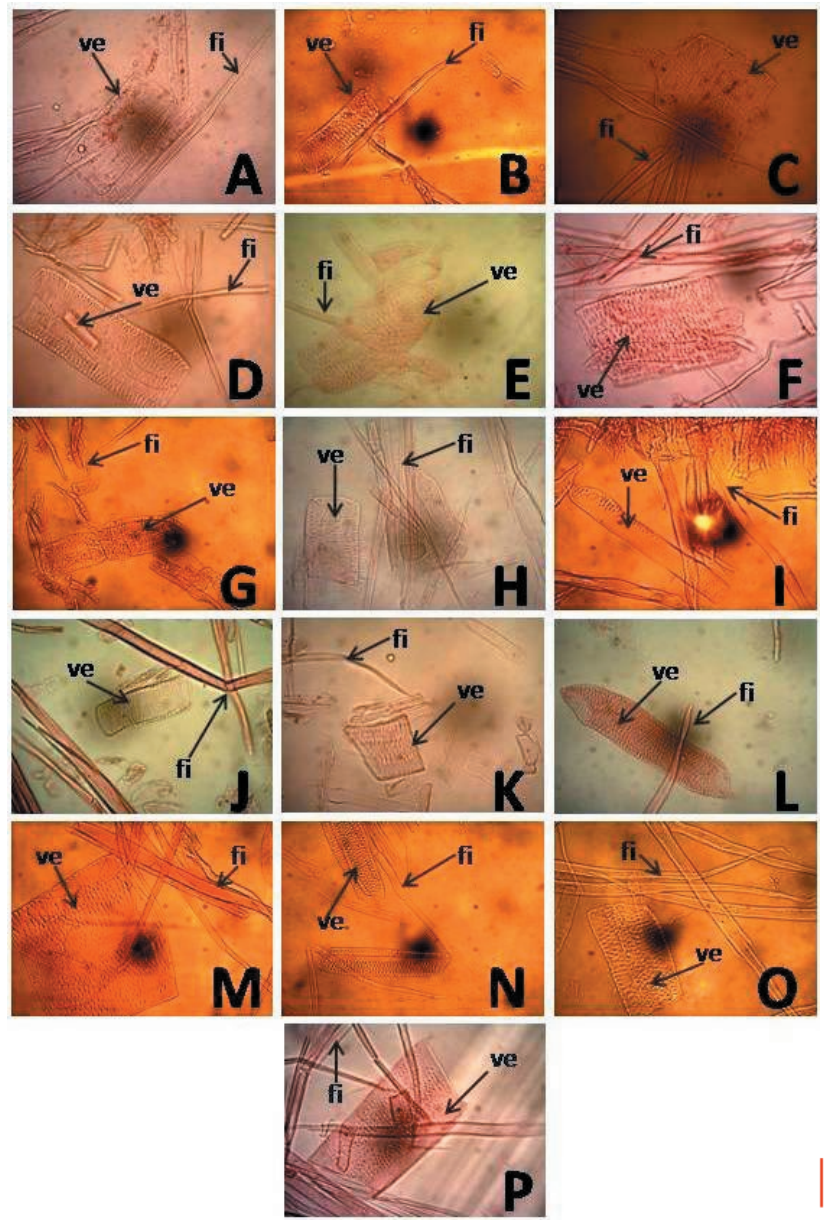

Figure 5. Wood macerates of Dalbergieae species in Nigeria. Mg.x400. A- Andira inermis; B-Dalbergia albiflora; C- Dalbergia ecastaphyllum; D- Dalbergia hostilis; E-Dalbergia lactea; F-Dalbergia latifolia; G-Dalbergia melanoxylon; H-Dalbergia oligophylla; I-Dalbergia rufa; J-Dalbergia saxatilis; K-Dalbergia sissoo; L-Machaerium lunatum; M-Pterocarpus erinaceus; N-Pterocarpus lucens; O-Pterocarpus mildbraedii; P-Pterocarpus osun. fi- fibre; vevessel elements.

have axial parenchyma except for $D$. rufa and D. lactea. In $P$. mildbraedii, $P$. erinaceus, $P$. lucens, $P$. osun, D. melanoxylon, D. oligophylla, D. sissoo, D. ecastaphyllum, D. hostilis, and M. lunatum, it is diffuse in aggregate while in others it was either winged or paratrecheal aliform, confluent and diffuse. According to Wickremasinghe and Herat (2006), features of wood ray tissues are important in deducing evolutionary sequences within angiosperm groups. In the present study, ray type varied from heterogenous in P. osun to a combination of uniseriate, biseriate, multiseriate, non-storied, and heterogeneous in other species. Simply put, the presence of uniseriate ray cells observed in almost all the species except $D$. ecastaphyllum and A. inermis, is a diagnostic feature of phylogenetically 


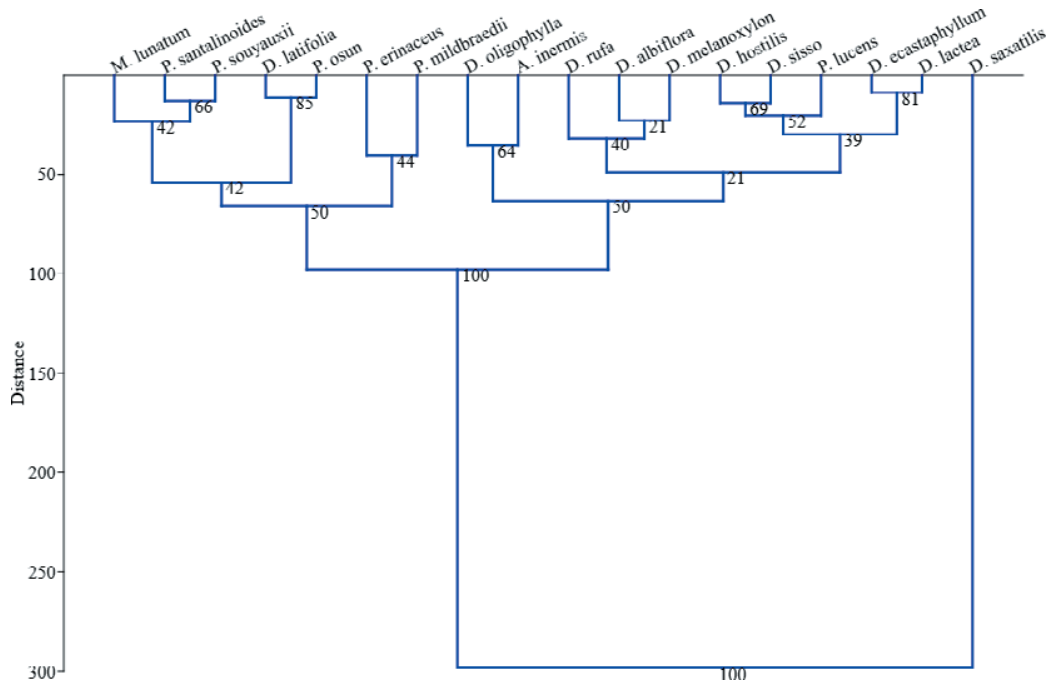

Figure 6. Dendrogram (UPGMA) of Dalbergieae species based on euclidean distance.

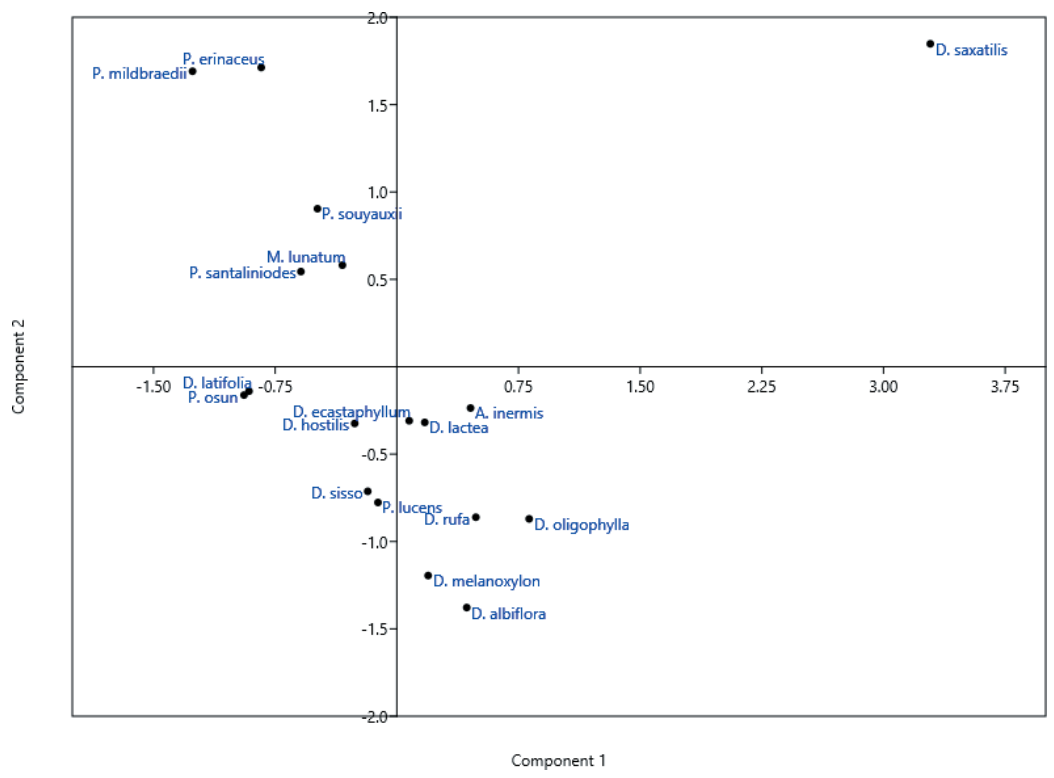

Figure 7. Scatter plot of species of Dalbergieae studied based on the wood anatomical characters.

advanced taxa (Metcalfe and Chalk, 1989), and important in depicting the evolutionary sequence of specialization within angiosperms (Kribs, 1935). However, the rays are non-storied which is quite different from the observations of Lavin et al. (2001), who earlier recorded storied rays and axial parenchyma in legumes; but conforms to their report of heterogeneous rays in juvenile wood samples as used in this study.

All studied species have crystals that were either prismatic or styloid or both and this may not be a diagnostic feature. It was also observed that most of the studied species have tylose except $P$. santalinoides, $P$. erinaceus, D. melanoxylon, D. rufa, D. ecastaphyllum, D. latifoila, M. lunatum. This character is also considered an indication of evolutionary primitiveness (Bonsen and Kucera, 1990 in: Wickremasinghe and Herat, 2006). The presence of non-septate, non-storied fibres observed in all of them is of no taxonomic importance, unlike septate fibres which are important taxonomic tools (Metcalfe and Chalk, 1989).

Quantitative features as observed in this study revealed that the average number of vessels per square millimeter may not be taxonomically important as a classificatory and diagnostic character for this taxon; 
Table 5. Similarity indices (Euclidean) for the examined species of Dalbergieae based on wood anatomical characters.

\begin{tabular}{|c|c|c|c|c|c|c|c|c|c|c|c|c|c|c|c|c|c|c|}
\hline Species & 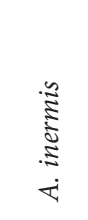 & $\begin{array}{l}\stackrel{0}{0} \\
\stackrel{5}{0} \\
\stackrel{0}{0} \\
0\end{array}$ & 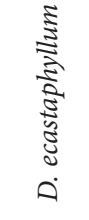 & 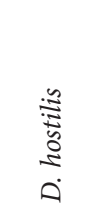 & $\frac{\tilde{\Xi}}{\stackrel{\Xi}{\Xi}}$ & 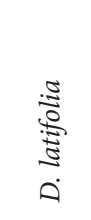 & 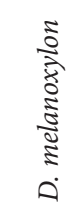 & 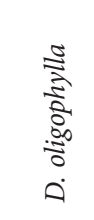 & $\frac{\mathbb{5}}{5}$ & 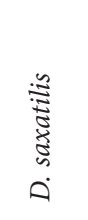 & 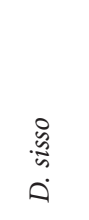 & 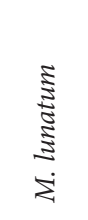 & 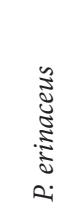 & 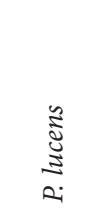 & 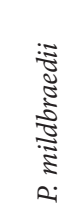 & $\begin{array}{l}\tilde{3} \\
\vdots \\
0 \\
0 \\
2\end{array}$ & 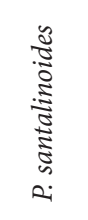 & 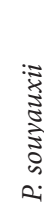 \\
\hline A. inermis & 0 & & & & & & & & & & & & & & & & & \\
\hline D. albiflora & 48.12 & 0 & & & & & & & & & & & & & & & & \\
\hline D. ecastaphyllum & 44.28 & 41.69 & 0 & & & & & & & & & & & & & & & \\
\hline D. hostilis & 62.69 & 66.69 & 30.61 & 0 & & & & & & & & & & & & & & \\
\hline D. lactea & 37.19 & 36.87 & 8.88 & 37.39 & 0 & & & & & & & & & & & & & \\
\hline D. latifolia & 133.40 & 121.29 & 91.14 & 74.23 & 99.61 & 0 & & & & & & & & & & & & \\
\hline D. melanoxylon & 56.39 & 22.96 & 30.26 & 51.76 & 30.24 & 99.73 & 0 & & & & & & & & & & & \\
\hline D. oligophylla & 35.30 & 51.41 & 71.13 & 93.09 & 62.96 & 161.34 & 69.85 & 0 & & & & & & & & & & \\
\hline D. rufa & 61.33 & 29.03 & 47.68 & 76.07 & 43.49 & 120.67 & 35.09 & 65.99 & 0 & & & & & & & & & \\
\hline D. saxatilis & 248.52 & 254.18 & 3275.08 & 303.62 & 267.59 & 355.01 & 271.15 & 5225.10 & 245.44 & 0 & & & & & & & & \\
\hline D. sisso & 57.88 & 57.56 & 28.28 & 14.05 & 34.20 & 80.91 & 43.20 & 85.57 & 71.38 & 299.43 & 0 & & & & & & & \\
\hline M. lunatum & 77.26 & 83.37 & 42.64 & 29.95 & 49.37 & 64.90 & 67.39 & 109.34 & 82.84 & 305.14 & 42.66 & 0 & & & & & & \\
\hline P. erinaceus & 122.74 & 134.95 & 93.91 & 73.32 & 100.58 & 66.21 & 117.62 & 2156.61 & 135.34 & 345.25 & 85.58 & 53.61 & 0 & & & & & \\
\hline P. lucens & 60.04 & 48.62 & 20.77 & 22.68 & 27.85 & 77.57 & 30.86 & 85.16 & 57.51 & 293.34 & 18.12 & 41.63 & 90.43 & 0 & & & & \\
\hline P. mildbraedii & 152.64 & 165.62 & 125.54 & 4100.12 & 132.41 & 82.63 & 148.27 & 7186.98 & 167.76 & 381.89 & 112.02 & 85.53 & 40.56 & 118.56 & 0 & & & \\
\hline P. osun & 134.75 & 123.11 & 192.69 & 75.17 & 101.06 & 11.48 & 101.96 & 5163.03 & 121.57 & 357.59 & 82.72 & 64.77 & 66.71 & 78.84 & 79.98 & 0 & & \\
\hline P. santalinoides & 98.53 & 99.79 & 61.12 & 42.17 & 69.08 & 43.38 & 80.65 & 130.13 & 100.48 & 325.89 & 53.28 & 25.17 & 40.32 & 53.79 & 70.99 & 44.84 & 0 & \\
\hline P. souyauxii & 94.40 & 98.43 & 58.57 & 44.64 & 65.96 & 52.69 & 80.35 & 126.35 & 97.27 & 316.49 & 55.93 & 21.71 & 39.79 & 55.66 & 75.27 & 54.67 & 13.09 & 0 \\
\hline
\end{tabular}

as neither very low nor very high measurements were obtained, the range is between $1.71 \mu \mathrm{m} \pm 0.1$ (D. latifolia) and $9.42 \mu \mathrm{m} \pm 0.5$ (D. melanoxylon) (Metcalfe and Chalk (1989). Mean pore diameter ranges between 0.04 $\mu \mathrm{m} \pm 0.3$ in $M$. lunatum and $0.09 \mu \mathrm{m} \pm 0.9$ in $P$. soyauxii and $P$. osun. On average, the longest fibre was observed in $P$. midbraedii $(331.22 \mu \mathrm{m} \pm 7.5)$ while the shortest fibre was seen in the macerated wood of D. oligophylla $(150.98 \mu \mathrm{m} \pm 4.1)$. According to Maiti et al. (2016), the presence of big vessels in plants makes them susceptible to drought and therefore may possess a deep root system to adapt to this condition. However, all studied species have relatively small vessels because they are not found in arid habitats. As evidenced in this study, the woods of members of the tribe Dalbergieae have more generic/tribal characteristics than delimiting characters. Distributional information also clearly showed that members of the tribe occur in all the geoecological zones of Nigeria but are most widely distributed around the Southern region. This could be attributed to the high rainfall or precipitation characterized by this area which also enhances species growth and development compared to species in the Northern area. Given the continuous habitat degradation in the south however, the distribution of the species may decline further. Hence, it is imperative to consider the sustainable collection and use of plant genetic resources on one hand, and the conservation of our remaining forest estates on the second hand, else we loose our biodiversity to climate change.

\section{CONCLUSION}

The present study examined the wood anatomical features of some species of the tribe Dalbergieae in Nigeria. Results have shown that the porosity of the wood of all species studied was diffuse and the vessels have simple perforation plate. All except $P$. osun lacked secretory ducts; and possess non-septate fibres. However, few of the species lacked tylose. Crystals were either prismatic, styloid or a combination of both. Generally, wood micro- characteristics across all the species overlapped, yet, certain characters can be utilized in distinguishing the taxa. While we recognize the importance of molecular data in recent studies, we advocate that other aspects such as macro and micro-morphology should not be ignored, as they provide supplementary information to aid the taxonomic understanding of species. 


\section{ACKNOWLEDGMENTS}

The authors are grateful to the management of Forest Herbarium Ibadan (FHI) and University of Ibadan Herbarium (UIH) for the availability of specimens and ecological information utilized for this study.

\section{REFERENCES}

Aguoru CU, Okoli BE. 2008. Systematic Description of Momordica (Cucurbitaceae): Synopsis of the Tropical West African Species of Momordica L. International Journal of Tropical Agriculture and Food Systems. 2: 71-76. https://doi.org/10.4314/ijotafs.v2i1.40963

Akinloye AJ, Illoh HC, Olagoke OA. 2012. Significance of wood anatomical features to the taxonomy of five Cola species. Sustainable Agriculture Research. 1(2):21-26. https://doi.org/10.5539/SAR.V1N2P21

Arogundade OO, Adedeji O. 2019. Taxonomic significance of the vegetative anatomy of members of genera Colocasia (L.) Schott and Xanthosoma (L.) Schott in the family Araceae. African Journal of Plant Science. 13(4): 92-106. https://doi.org/10.5897/ AJPS2019.1776

Baretta-Kuipers T. 1981. Wood anatomy of Leguminosae: its relevance to taxonomy. In: Polhill RM, Raven PH. (eds.), Advances in legume systematics, part 2: 677-705. Royal Botanic Gardens, Kew, Richmond, Surrey, UK

Bentham G. 1865. Leguminosae. In: Bentham G, Hooker JD. (eds.), Genera plantarum, vol. 1. . Pp. 434-600 London: Reeve.

Bonsen KJM, Kucera LJ. 1990. Vessel occlusion in plants: Morphological and evolutionary aspects. International Association of Wood Anatomists Bulletin. 11(4): 393-399. https://doi.org/10.1163/22941932-90000528

Cardoso D, Pennington RT, de Queiroz LP, Boatwright JS, Van Wyk BE, Wojciechowski MF, Lavin M. 2013. Reconstructing the deep-branching relationships of the papilionoid legumes. South African Journal of Botany. 89: 58-75. https://doi.org/10.1016/j. sajb.2013.05.001

Carlquist S. 1961. Comparative Plant Anatomy. Holt Rinehart and Wintson, NewYork.

Corby HDL. 1981. The systematic value of leguminous root nodules. In: Polhill RM, Raven PH. (eds.), Advances in legume systematics, part 2, pp657-669. Royal Botanic Gardens, Kew, Richmond, Surrey, UK.

de Candolle AP. 1825. Prodromus systematis naturalis regni vegetabilis, vol. 2(1). Paris: Treuttel and Würtz.

Doyle JJ, Chappill JA, Bailey CD, Kajita T. 2000. Towards a comprehensive phylogeny of legumes: Evidence from $\mathrm{rbcL}$ sequences and non-molecular data. In: Herendeen PS, Bruneau A. (eds.), Advances in legume systematics, part 9: 1-20. Richmond, U.K.: Royal Botanic Gardens, Kew, UK

Fabre S, Gully D, Poitout A, Patrel D, Arrighi JF, Giraud E, Czernic P, Cartieaux F. 2015. Nod Factor-Independent Nodulation in Aeschynomeneevenia Required the Common Plant-Microbe Symbiotic Toolkit1. Plant Physiology. 169: 2654-2664.

Gillett JB, Polhill RM, Verdcourt B, Schubert BG, MilneRedhead E, Brummitt RK. 1971. Leguminosae (Parts 3-4), subfamily Papilionoideae (1-2). In: Milne-Redhead E, Polhill RM. (eds.). Flora of Tropical East Africa. 1108 pp. Crown Agents for Oversea Governments and Administrations, London, United Kingdom.

Hammer $\varnothing \mathrm{H}$, David AT, Ryan PD. 2001. PAST: Paleontological statistics software package for education and data analysis. Palaeontologia Electronica. 4: 4-9.

Herendeen PS, Miller RB. 2000. Utility of wood anatomical characters in cladistic phylogenetic analyses. IAWA Journal. 21: 247-276. https://doi. org/10.1163/22941932-90000247

Holmgren PK, Keuken W, Scho4eld EK. 1990. Index Herbariorum Part I. 7e Herbaria of the World. 8th ed. Reg. Veg., - New York. Also available and updated at: http://sweetgum.nybg.org/science/ih/

IAWA Committee. 1989. IAWA list of microscopic features for hard wood identification. Wheeler, E.A., Baas, P. and Gasson, P.E. (Eds.). IAWA Bull, ns. 10 (3): 219-332

Kajita T, Ohashi H, Tateishi Y, Bailey CD. Doyle JJ. 2001. $\mathrm{rbcL}$ and legume phylogeny, with particular reference to Phaseoleae, Millettieae, and allies. Systematic Botany. 26: 515-536.

Kribs DA. 1935. Salient lines of structural specialization in the wood rays of dicotyledons. Bot Gaz. 96: 547557.

Kribs DA. 1937. Salient lines of structural specialization in the wood parenchyma of dicotyledons. Bulletin of the Torrey Botanical Club. 64: 177 - 187

Lavin M, Pennington RT, Klitgaard BB, Sprent JI, de Lima HC, Gasson PE. 2001. The dalbergioid legumes (Fabaceae): delimitation of a pantropical monophyletic clade. American Journal of Botany. 88 (3): 50333. https://doi.org/10.2307/2657116

Lewis G, Schrire B, Mackinder B, Lock M. (eds.) 2005. Legumes of the world. Richmond, U.K.: Royal Botanic Gardens, Kew.

Lima HC De. 1990. Tribo Dalbergieae (LeguminosaePapilionoideae) - Morfologia dos frutos, sementes e plântulas e sua aplicação na sistemática. Arquivos do Jardim Botânico do Rio de Janeiro. 30: 1-4 
Liu Y, Zhou L, Zhu Y, Liu S. 2020. Anatomical features and its radial variations among different Catalpa bungei clones. Forests. 11: 824: 1-17. http://dx.doi. org/10.3390/f11080824

LPWG. 2013. Legume phylogeny and classification in the 21st century: progress, prospects and lessons for other species-rich clades. Taxon. 62(2):217-248. https:// doi.org/10.12705/622.8

LPWG. 2017. A new subfamily classification of the Leguminosae based on a taxonomically comprehensive phylogeny. Taxon. 66(1):44-77. https://doi. org/10.5061/dryad.61pd6

Mabberley DJ. 1997. The Plant-Book. 2nd Edition, Cambridge University Press, Cambridge, UK.

Maiti R, Rodriguez HG, Para AC, Aruna Kumari CH, Sarkar NC. 2016. A Comparative Wood Anatomy of 15 Woody Species in North-eastern Mexico. Forest Research. 5: 166. https://doi.org/10.4172/21689776.1000166

Metcalfe CR, Chalk L. 1979. Anatomy of the Dicotyledons v. 1: Systematic Anatomy of Leaf and Stem; With a Brief History of the Subject. v. 2: Wood Structure and Conclusion of the General Introduction.

Metcalfe CR, Chalk L. 1989. Anatomy of the Dicotyledons 2nd ed. Vol. 11, Clarendreon Press, Oxford.

Ogbonnaya CI, Roy-Macauley H, Nwalozie MC, Annerose DJM. 1997. Physical and histochemical properties of Kenaf (Hibiscus cannabinus L.) grown under water deficit on a sandy soil. Industrial crops and products. 7: 9-18. https://doi.org/10.1016/S09266690(97)00034-4

Oladipo OT, Oyaniran AO. 2013. Taxonomic study of the wood anatomy of the genus Ocimum L. in Nigeria. Ife Journal of Science. 15(2):95-302

Pennington RT, Lavin M, Ireland H, Klitgaard BB, Preston J, Hu JM. 2001. Phylogenetic relationships of basal papilionoid legumes based upon sequences of the chloroplast trnL intron. Systematic Botany. 26: 537-556.

Polhill R.M. 1981. Dalbergieae. In R. M. Polhill and P. H. Raven (eds.), Advances in legume systematics, part 1, pp233-242. Royal Botanic Gardens, Kew, Richmond, Surrey, UK

Sharma V, Bhattacharyya S, Kumar R, Kumar A, Ibañez F, Wang J, Guo B, Sudini HK, Gopalakrishnan S, DasGupta M, Varshney RK, Pandey MK. 2020. Molecular Basis of Root Nodule Symbiosis between Bradyrhizobium and 'Crack-Entry' Legume Groundnut (Arachis hypogaea L.).Plants. 9(2) 276. https:// doi.org/10.3390/plants9020276

Soladoye MO, Lewis GP. 2003. A Checklist of Nigerian Legumes. CENRAD Natural Resources Research
Assessment and Conservation Series 03. Ibadan, Nigeria, West Africa.

Sprent JI, James EK. 2007. Legume Evolution: Where Do Nodules and Mycorrhizas Fit In? Plant Physiol. 144: 575-581.

Wickremasinghe BKL, Herat TR. 2006. A comparative wood anatomical study of the genus Diospyros L. (Ebenaceae) in Sri Lanka. Ceylon Journal of Science (Biological Sciences). 35 (2): 115-136.

Wojciechowski MF, Lavin M, Sanderson MJ. 2004. A phylogeny of the legumes (Leguminosae) based on analysis of the plastid matK gene sequences resolves many well-supported subclades within the family. American Journal of Botany. 91: 1846-1862. http:// dx.doi.org/10.3732/ajb.91.11.1846

Wojciechowski MF. 2003. Reconstructing the phylogeny of legumes (Leguminosae): An early 21st century perspective. In: Klitgaard, B.B. and Bruneau, A. (eds.), Advances in legume systematics, part 10, pp. 5-35. Higher level systematics. Richmond, U.K.: Royal Botanic Gardens, Kew.

Wojciechowski MF. 2013. Towards a new classification of Leguminosae: Naming clades using non-Linnaean phylogenetic nomenclature. South African Journal of Botany. 89: 85-93. https://doi.org/10.1016/j. sajb.2013.06.017 